\section{Obsessive-compulsive disorder and 5-HTTLPR}

\author{
Transtorno obsessivo-compulsivo e 5-HTTLR
}

Dear Editor,

According to the Diagnostic and Statistical Manual of Mental Disorders (Fourth Edition), obsessive-compulsive disorder (OCD) is a debilitating neuropsychiatric condition ${ }^{1,2}$. Although there is strong evidence of genetic contribution, susceptibility locus has not yet been identified ${ }^{3,4}$.

The serotonin system plays an important role in the pathogenesis of OCD as demonstrated mainly by the efficacy of serotoninreuptake inhibitors. ${ }^{1,2}$ Genetic variations in the serotonin transporter gene (SLC6A4) may be involved in the vulnerability to psychiatric disorders, including OCD. ${ }^{2-4} \mathrm{~A}$ common polymorphism located in the promoter region (5-HTTLPR) and consisting of either the insertion or deletion of 44 base pairs has been suggested to be associated to OCD. ${ }^{3,4}$ The 5-HTTLPR has two variants: the long variant $(\mathrm{L})$, which has been reported to generate more gene expression than the short one (S). Moreover, the $\mathrm{S}$ allele is less efficient in the uptake of serotonin. ${ }^{2-4}$ More recently, it has been suggested that 5-HTTLPR could be functionally triallelic ( $\mathrm{La}, \mathrm{Lg}$, and S). The $\mathrm{L}$ allele with a common $\mathrm{G}$ substitution ( $\mathrm{Lg}$ ) has shown to have lower expression than the La and nearly equivalent expression compared to the $\mathrm{S}$ allele. ${ }^{3}$

Although several researchers have studied OCD and 5-HTTLPR, their findings are controversial and inconclusive. We sought to investigate this association in a sample of 92 Brazilian-Caucasian OCD patients and 115 matched healthy controls. The study was approved by the Ethics Committee of the Hospital das Clínicas of the Universidade Federal de Minas Gerais (UFMG) and all participants were required to sign informed consent forms.

Genomic DNA was extracted from venous blood samples and the polymorphism was analyzed as described previously. ${ }^{2}$ We used a chi-square test for the analysis of the differences between OCD patients and controls ${ }^{2-4}$ with regards to allele and genotype frequencies by grouping S- and/or Lg-carriers in view of the fact that they act in a nearly dominant way and have equivalent expression.

The genotypic distributions were in Hardy-Weinberg equilibrium. The La allele was associated to OCD $(\mathrm{OR}=1.36 ; 1.15<\mathrm{OR}<$ 1.87; $p=0.002)$ but we did not find differences in genotypic distribution $(p=0.54)$.
Our results are similar to those found in an important recent study that associated the La allele to OCD. ${ }^{3}$ Although several previous results had been inconsistent, this association may be significant only in certain subgroups, such as that of Caucasian patients. ${ }^{3}$ Moreover, earlier biallelic studies have classified the Lg variant as the long-form of the allele, a fact which may partially account for these contradictory results ${ }^{3,4}$.

The fact that our sample consisted of Caucasian patients may account for the results achieved. Although our sample was comprised only of self-defined Caucasian-Brazilian individuals, race (as determined by self and/or clinical evaluation) is a poor predictor of ancestry in Brazil and, therefore, it cannot be ruled out that a certain bias towards ethnic stratification did exist ${ }^{5}$.

More studies with triallelic model and more homogeneous groups are required to clarify the contribution of genetics to OCD.

Felipe Filardi da Rocha, Luiz Armando de Marco Pharmacology and Molecular Biochemistry Program, Universidade Federal de Minas Gerais (UFMG),

Belo Horizonte, Brazil

Marco Aurélio Romano-Silva, Humberto Corrêa Pharmacology and Molecular Biochemistry Program, Universidade Federal de Minas Gerais (UFMG), Belo Horizonte (MG), Brazil

Department of Mental Health, Faculty of Medicine, Universidade Federal de Minas Gerais (UFMG), Belo Horizonte (MG), Brazil 


\section{Disclosures}

\begin{tabular}{|c|c|c|c|c|c|c|c|}
\hline $\begin{array}{l}\text { Writting group } \\
\text { member }\end{array}$ & Employment & $\begin{array}{l}\text { Research } \\
\text { grant }^{1}\end{array}$ & $\begin{array}{c}\text { Other research grant or } \\
\text { medical continuous } \\
\text { education }\end{array}$ & $\begin{array}{l}\text { Speaker's } \\
\text { honoraria }\end{array}$ & $\begin{array}{l}\text { Ownership } \\
\text { interest }\end{array}$ & $\begin{array}{c}\text { Consultant/ } \\
\text { Advisory board }\end{array}$ & Other $^{3}$ \\
\hline $\begin{array}{l}\text { Felipe Filardi da } \\
\text { Rocha }\end{array}$ & $\begin{array}{l}\text { Hospital Galba Velloso } \\
\text { Faculdade de Medicina } \\
\text { do Vale do Aço }\end{array}$ & $\mathrm{CNPq}^{\star \star *}$ & - & - & - & - & - \\
\hline $\begin{array}{l}\text { Luiz Armando de } \\
\text { Marco }\end{array}$ & UFMG & $\mathrm{CNPq}^{\star \star \star}$ & - & - & - & - & - \\
\hline $\begin{array}{l}\text { Marco Aurélio } \\
\text { Romano-Silva }\end{array}$ & UFMG & $\mathrm{CNPq}^{* * *}$ & - & - & - & - & - \\
\hline Humberto Corrêa & UFMG & $\mathrm{CNPq}^{* * *}$ & - & - & - & - & - \\
\hline
\end{tabular}

* Modest

** Significant

*** Significant. Amounts given to the author's institution or to a colleague for research in which the author has participation, not directly to the author.

Note: UFMG = Universidade Federal de Minas Gerais; $C N P q=$ Conselho nacional de Desenvolvimento Científico e Tecnológico.

For more information, see Instructions for authors.

\section{References}

1. Miguel EC, Ferrão YA, do Rosário MC, de Mathis MA, Torres AR, Fontenelle LF, Hounie AG, Shavitt RG, Cordioli AV, Gonzalez CH, Petribú K, Diniz JB, Malavazzi DM, Torresan RC, Raffin AL, Meyer E, Braga DT, Borcato S, Valério C, Gropo LN, Prado Hda S, Perin EA, Santos SI, Copque H, Borges MC, Lopes AP, da Silva ED; Brazilian Research Consortium on Obsessive-Compulsive Spectrum Disorders. The Brazilian Research Consortium on Obsessive-Compulsive Spectrum Disorders: recruitment, assessment instruments, methods for the development of multicenter collaborative studies and preliminary results. Rev Bras Psiquiatr. 2008;30(3):185-96.

2. da Rocha FF, Malloy-Diniz L, Lage NV, Romano-Silva MA, de Marco LA, Correa $\mathrm{H}$. Decision-making impairment is related to serotonin transporter promoter polymorphism in a sample of patients with obsessive-compulsive disorder. Behav Brain Res. 2008;195(1):159-63.
3. Hu XZ, Lipsky RH, Zhu G, Akhtar LA, Taubman J, Greenberg BD, Xu K, Arnold PD, Richter MA, Kennedy JL, Murphy DL, Goldman D. Serotonin transporter promoter gain-of-function genotypes are linked to obsessive-compulsive disorder. Am J Hum Genet. 2006;78(5):815-26.

4. Bloch MH, Landeros-Weisenberger A, Sen S, Dombrowski P, Kelmendi B, Coric V, Pittenger C, Leckman JF. Association of the serotonin transporter polymorphism and obsessive-compulsive disorder: systematic review. Am J Med Genet B Neuropsychiatr Genet. 2008;147B(6):850-8.

5. Parra FC, Amado RC, Lambertucci JR, Rocha J, Antunes CM, Pena SD. Color and genomic ancestry in Brazilians. Proc Natl Acad Sci USA. 2003;100(1):177-82. 